\title{
Effect of coffee drinking on platelets: inhibition of aggregation and phenols incorporation
}

\author{
F. Natella ${ }^{1}$, M. Nardini ${ }^{1}$, F. Belelli ${ }^{1}$, P. Pignatelli ${ }^{2}$, S. Di Santo ${ }^{2}$, A. Ghiselli ${ }^{1}$, F. Violi ${ }^{2}$ and C. Scaccini ${ }^{1}$ \\ ${ }^{1}$ National Research Institute on Food and Nutrition, INRAN, Via Ardeatina 546, 00178 Roma, Italy \\ ${ }^{2}$ Institute of 1 st Clinical Medicine, University La Sapienza, Policlinico Umberto I 00185, Roma, Italy
}

(Received 8 November 2007 - Revised 10 March 2008 - Accepted 17 March 2008 - First published online 28 April 2008)

Epidemiological studies indicate a J-shaped relationship linking coffee consumption and cardiovascular risk, suggesting that moderate coffee consumption can be beneficial. Platelet aggregation is of critical importance in thrombotic events, and platelets play a major role in the aetiology of several CVD. The aim of this study was to evaluate the effect of coffee drinking on platelet aggregation ex vivo, using caffeine as control. A crossover study was performed on ten healthy subjects. In two different sessions, subjects drank $200 \mathrm{ml}$ coffee, containing $180 \mathrm{mg}$ caffeine, or a capsule of caffeine $(180 \mathrm{mg}$ ) with $200 \mathrm{ml}$ water. Platelets were separated from plasma at baseline and 30 and 60 min after coffee drinking. Platelet aggregation was induced with three different agonists: collagen, arachidonic acid and ADP. Coffee drinking inhibited collagen $(P<0.05$ from baseline at time $30 \mathrm{~min})$ and arachidonic acid $(P<0.05$ from baseline at time $60 \mathrm{~min})$ induced platelet aggregation. Caffeine intake did not affect platelet aggregation induced by the three agonists. Coffee consumption induced a significant increase of platelet phenolic acids (likely present as glucuronate and sulphate derivatives), caffeic acid, the principal phenolic acid in coffee, raising from $0 \cdot 3$ (SEM $0 \cdot 1$ ) to $2.4($ SEM 0.6$) \mathrm{ng} / \mathrm{mg}(P<0.01)$. Caffeine was not detectable in platelets. Coffee drinking decreases platelet aggregation, and induces a significant increase in phenolic acid platelet concentration. The antiplatelet effect of coffee is independent from caffeine and could be a result of the interaction of coffee phenolic acids with the intracellular signalling network leading to platelet aggregation.

Cardiovascular diseases: Coffee: Human: Phenolic acids: Platelet aggregation

Coffee is among the most widely consumed beverages in the world. The relationship between coffee drinking and CVD has been extensively studied. Recently several studies indicate a moderate coffee consumption can be protective against cardiovascular risk ${ }^{(1-3)}$. The effect of coffee on platelet aggregation has been poorly studied. Although the main physiologic effects resulting from coffee consumption are usually ascribed to the presence of caffeine, coffee is also an extremely rich source of phenolic acids, mostly in the form of chlorogenic acid. The chlorogenic acid content of coffee is very similar to that of caffeine; a cup of American coffee contains, in fact, about $170 \mathrm{mg}$ chlorogenic acid and $180 \mathrm{mg}$ caffeine ${ }^{(4)}$. The daily intake of chlorogenic acid in coffee drinkers ranges from 0.5 to $1.0 \mathrm{~g}^{(5)}$, and the presence of coffee phenolic acids in plasma after coffee drinking is well documented ${ }^{(6)}$.

Several epidemiological studies have reported a negative association between the intake of dietary polyphenols and the risk for $\mathrm{CVD}^{(7,8)}$. The activity of dietary polyphenols on CVD has been attributed to both their antioxidant activity in preventing LDL oxidation, and to their effect on the pathogenesis of thrombosis by interfering with platelet activation and function. Platelets play an important role not only in the formation of acute thrombus and vessels occlusion, but also in the development of atherosclerosis and $\mathrm{CVD}^{(9)}$. Moreover, ex vivo platelet aggregation is related to CVD mortality ${ }^{(10)}$.

Phenolic compounds are capable of inhibiting platelet aggregation both in vitro ${ }^{(11,12)}$ and in vivo ${ }^{(13,14)}$. It has been demonstrated that phenolic-rich beverages, such as cocoa, tea and wine, can inhibit platelet aggregation both in vitro ${ }^{(11,15,16)}$ and

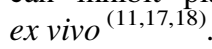

In 1987 Bydlowski et al. ${ }^{(19)}$ demonstrated that coffee extracts could inhibit in vitro platelet aggregation induced by ADP or arachidonic acid, but not by collagen, and were effective in inhibiting platelet aggregation ex vivo after intravenous administration in rabbits. More recently, Polagruto et al. ${ }^{(20)}$ did not find any effect on platelet function (assessed by a Platelet Function Analyser PFA-100) in man 2 or $6 \mathrm{~h}$ after instant coffee consumption.

The aim of the present study was to: (1) evaluate ex vivo the effect of coffee on platelet aggregation and (2) investigate in vivo the platelet uptake of coffee phenolic acids. As both caffeine $^{(21,22)}$ and phenolics ${ }^{(11,23)}$ have been suggested to affect platelet aggregation, the present study was performed using caffeine as control. 


\section{Subjects and methods}

\section{Subjects and study design}

Ten volunteers (five males and five females), aged 24-35 years, participated in a cross-over study. Subjects, free from known diseases and moderate coffee drinkers (two to four cups/d), were instructed to refrain from consuming coffee and phenol-rich foods and beverages for the $2 \mathrm{~d}$ prior to the experiments. Subjects were also asked to abstain from any platelet inhibitor and dietary supplements for $\geq 10 \mathrm{~d}$ prior to the experiments. Subjects reported to the laboratory on two separate occasions, 2-4 weeks apart, after an overnight fast $(10-12 \mathrm{~h})$. A venous blood sample was taken at time 0 . Immediately after the first blood collection subjects were provided with a cup of freshly prepared American coffee $(200 \mathrm{ml})$ or a capsule containing $180 \mathrm{mg}$ caffeine with $200 \mathrm{ml}$ water. This dose was equivalent to the caffeine contained in the cup of coffee. Further blood collections were made 30 and $60 \mathrm{~min}$ after coffee or caffeine consumption. Venous blood samples were collected into evacuated tubes containing sodium citrate. Platelet-rich plasma (PRP) was separated by low-speed centrifugation $(180 \mathrm{~g}, 15 \mathrm{~min})$ at room temperature.

All subjects gave informed consent before entering the study, and all procedures were approved by the Ethical Committee of the National Institute for Food and Nutrition Research.

\section{Coffee brew preparation and analyses}

Coffee brew was prepared by using a commercial automatic brewing machine, using $60 \mathrm{~g}$ roasted and ground coffee per litre of water.

Caffeine was measured in coffee by HPLC as previously described by Blanchard et al. ${ }^{(24)}$, and the amount found after three replicate analyses (180 (SEM 9) mg/cup) was used for caffeine capsule formulation.

\section{Measurement of plasma caffeine concentrations}

Caffeine was detected in plasma and platelets by HPLC as previously described ${ }^{(24)}$.

\section{Measurement of platelet aggregation}

Platelet aggregation was measured ex vivo on PRP using an aggregometer, with constant stirring at $1000 \mathrm{rpm}$ and at $37^{\circ} \mathrm{C}$. PRP was separated from blood after 20 min centrifugation at $200 \mathrm{~g}$ and the number of platelets in the PRP was standardized at 300000 platelets $/ \mathrm{ml}$. To induce platelet aggregation, three different agonists were used: ADP $(2 \mu \mathrm{M})$, collagen $(3 \mu \mathrm{g} / \mathrm{ml})$ and arachidonic acid $(0.5 \mu \mathrm{M})$. Platelet aggregation was expressed as percentage of maximal aggregation.

For the in vitro experiments, we used PRP obtained from healthy subjects in fasting condition. PRP was standardized at 300000 platelets $/ \mathrm{ml}$ and pre-incubated $\left(30 \mathrm{~min}\right.$ at $\left.37^{\circ} \mathrm{C}\right)$ with a mix of caffeic acid $(2.4 \mathrm{ng} / \mathrm{mg}$ protein), ferulic acid $(1.9 \mathrm{ng} / \mathrm{mg}$ protein), $p$-coumaric acid $(1.8 \mathrm{ng} / \mathrm{mg}$ protein $)$ and isoferulic acid $(0.9 \mathrm{ng} / \mathrm{mg}$ protein), mimicking the concentrations of the phenolic acids measured in vivo. Platelet aggregation was induced by collagen $(3 \mu \mathrm{g} / \mathrm{ml})$ and measured as described earlier.

\section{Measurement of platelet thromboxane $B_{2}$ formation}

Thromboxane $\mathrm{B}_{2}(\mathrm{TxB} 2)$ production was measured in platelets separated at time 0,30 and $60 \mathrm{~min}$ after coffee drinking, on a sub-group of six subjects. PRP was incubated with collagen $(3 \mu \mathrm{g} / \mathrm{ml})$. The platelet activation was stopped after $10 \mathrm{~min}$ and thromboxane $\mathrm{A}_{2}$ (TxA2) production was determined using TxB2 (the stable breakdown product of TxA2) ELISA kits (R\&D System).

\section{Measurement of platelet phenolic acid concentrations}

Phenolic acids in biological samples are routinely detected in our laboratory by HPLC-electrochemical detector ${ }^{(25)}$. For the study of incorporation of phenolics in platelets, PRP was added with acid citrate dextrose and further centrifuged for $7 \mathrm{~min}$ at $780 \mathrm{~g}$. The pellet was washed once with PBS containing acid citrate dextrose, centrifuged and the final pellet was resuspended in water, sonicated, acidified to $\mathrm{pH}$ 3 with $1 \mathrm{M}-\mathrm{HCl}$ and stored at $-80^{\circ} \mathrm{C}$. The presence of phenolic acid into platelets was measured in samples untreated (free phenolic acids) and in samples subjected to alkaline hydrolysis (total phenolic acids) ${ }^{(6)}$.

No treatment. Platelet suspension $(0.5 \mathrm{ml})$ at $\mathrm{pH} 3$ was added with $50 \mathrm{ng} O$-coumaric acid as internal standard and $300 \mathrm{mg} \mathrm{NaCl}$, then extracted three times with ethyl acetate ( $\times 4$ volumes) by vortexing for $5 \mathrm{~min}$. After each extraction, samples were centrifuged $(3000 \mathrm{~g}, 10 \mathrm{~min}$, room temperature) and the supernatants collected. The organic phase was dried under nitrogen flow. The residue was dissolved in $0.5 \mathrm{ml}$ water, vortexed for $5 \mathrm{~min}$, then the $\mathrm{pH}$ was brought to $\mathrm{pH} 7-8$ with $0 \cdot 1 \mathrm{M}-\mathrm{NaOH}$ and sample passed through $1 \mathrm{ml}$ Supelclean LC-SAX tube preconditioned with $1 \mathrm{ml}$ absolute methanol and $2 \mathrm{ml}$ water. The tube was then washed with $1 \mathrm{ml}$ water. Phenolic acids elution was obtained with $1 \mathrm{ml}$ buffer containing $1 \mathrm{M}$-acetic acid-methanol (90:10). The eluant was immediately brought to $\mathrm{pH} 3$ with $6 \mu \mathrm{l}$ $4 \mathrm{M}-\mathrm{NaOH}$, filtered and an aliquot $(100 \mu \mathrm{l})$ was injected into the HPLC system.

Alkaline hydrolysis treatment. Platelet suspension $(0.5 \mathrm{ml})$ containing $50 \mathrm{ng} o$-coumaric acid as internal standard had the following added in order: $55 \mu \mathrm{l} \mathrm{H}_{2} \mathrm{O}, 20 \mu \mathrm{l} 0.5 \mathrm{M}$-EDTA, $200 \mu \mathrm{l} 5 \%$ ascorbic acid and $225 \mu \mathrm{l} 8 \mathrm{M}-\mathrm{NaOH}$, and was then incubated for $30 \mathrm{~min}$ at $30^{\circ} \mathrm{C}$. At the end of incubation, the $\mathrm{pH}$ was brought to 3 with $8 \mathrm{M}-\mathrm{HCl}$ and $600 \mathrm{mg} \mathrm{NaCl}$ added. Samples were extracted three times with ethyl acetate ( $\times 4$ volumes) as reported earlier. The residue was dissolved in $0.5 \mathrm{ml}$ water, vortexed for $5 \mathrm{~min}$, then processed for solidphase extraction as described earlier.

The overall procedures allow an almost complete recovery of the phenolic acids under study, as found by recovery experiments performed adding known amounts of pure compounds to platelet suspension samples. Recovery was 98.6 (SD 9.9), 95.4 (SD 13.6), 87.6 (SD 4.4), 100.7 (SD 5.7) (n 5) for caffeic, $p$-coumaric, ferulic and isoferulic acids, respectively.

Samples were analysed by HPLC-electrochemical detector as previously described ${ }^{(25)}$ with minor modifications concerning the elution gradient. 
Protein was measured by the method of Lowry et al. ${ }^{(26)}$, using bovine serum albumin as standard. The concentration of phenolic acids is expressed as ng/mg protein.

Free forms of phenolic acids in platelets were detected only at very low amounts (traces), therefore all the results presented refer to the total (free + bound) phenolic acid content.

\section{Statistics}

All data are presented as mean values with their standard errors. Statistical analysis was carried out using repeatedmeasures ANOVA, followed by Tukey's test for multiple comparisons. Analyses were performed with KaleidaGraph software version 3.6 (Synergy Software, Reading, PA, USA). $P<0.05$ was considered statistically significant.

\section{Results}

Effect of coffee and caffeine consumption on ex vivo platelet aggregation

Coffee drinking significantly inhibited platelet aggregation induced by arachidonic acid and collagen (Fig. 1), while no statistically significant differences were observed when ADP was used as agonist (Fig. 1).

Coffee drinking also inhibited collagen-induced TxB2 formation (Fig. 2).

Caffeine intake did not affect platelet aggregation induced by the three different agonists (Fig. 1).

\section{Effect of coffee and caffeine supplementation on plasma} caffeine concentrations

As expected, a statistically significant increase in plasma caffeine concentrations was detectable after both coffee and caffeine consumption (Fig. 3). However, the time course of caffeine increase was different in the two sessions, being slower after caffeine administration than after coffee consumption. Caffeine plasma concentrations measured after $30 \mathrm{~min}$ of caffeine intake $(15.2(\mathrm{SEM} 7 \cdot 8) \mu \mathrm{M})$ were, in fact, statistically significantly different from those observed 30 min after coffee drinking (20.6 (SEM 8.1) $\mu \mathrm{M})$.
Caffeine platelet concentration was under the detection limits of our method $(5 \mathrm{ng})$.

\section{Effect of coffee consumption on platelet phenolic acid concentration}

Coffee drinking induced a significant increase in phenolic acid platelet concentration (Table 1). All phenolic acids under study increased significantly, but they showed different incorporation kinetics. In fact, the maximum incorporation peak was at $30 \mathrm{~min}$ for $p$-coumaric and ferulic acids, and at 60 min for caffeic and isoferulic acids. The maximum concentration reached after coffee drinking was: $2.4 \mathrm{ng} / \mathrm{mg}$ protein for caffeic acid, $1.9 \mathrm{ng} / \mathrm{mg}$ protein for ferulic acid, $1.8 \mathrm{ng} / \mathrm{mg}$ protein for $p$-coumaric acid and $0.9 \mathrm{ng} / \mathrm{mg}$ protein for isoferulic acid.

The most relevant increases were observed for caffeic acid (8-fold at peak time with respect to time 0 ) and isoferulic acid ( $4 \cdot 5$-fold at peak time with respect to time 0$)$. $p$-Coumaric and ferulic acids increased more slightly, the increment of their concentration at peak time being about 60 and $90 \%$, respectively.

Phenolic acids were present in platelets almost exclusively as conjugated forms, free phenolic acids being present only as traces.

\section{Effect of phenolic acids on in vitro platelet aggregation}

To evaluate the capacity of phenolic acids in inhibiting platelet aggregation, a mix of phenolic acids was added to PRP at the concentrations measured in platelets after coffee drinking. After $30 \mathrm{~min}$ of incubation at $37^{\circ} \mathrm{C}$ aggregation was induced by collagen $(3 \mu \mathrm{g} / \mathrm{ml})$. As shown in Fig. 4 , the mix of phenolic acids was able to significantly inhibit platelet aggregation and collagen-induced TxB2 formation.

\section{Discussion}

The first aim of the present study was to determine the effects of coffee on ex vivo platelet aggregation induced by three different agonists (collagen, arachidonic acid and ADP), using caffeine as control. While coffee drinking inhibited collagen and arachidonic acid-induced platelet aggregation,
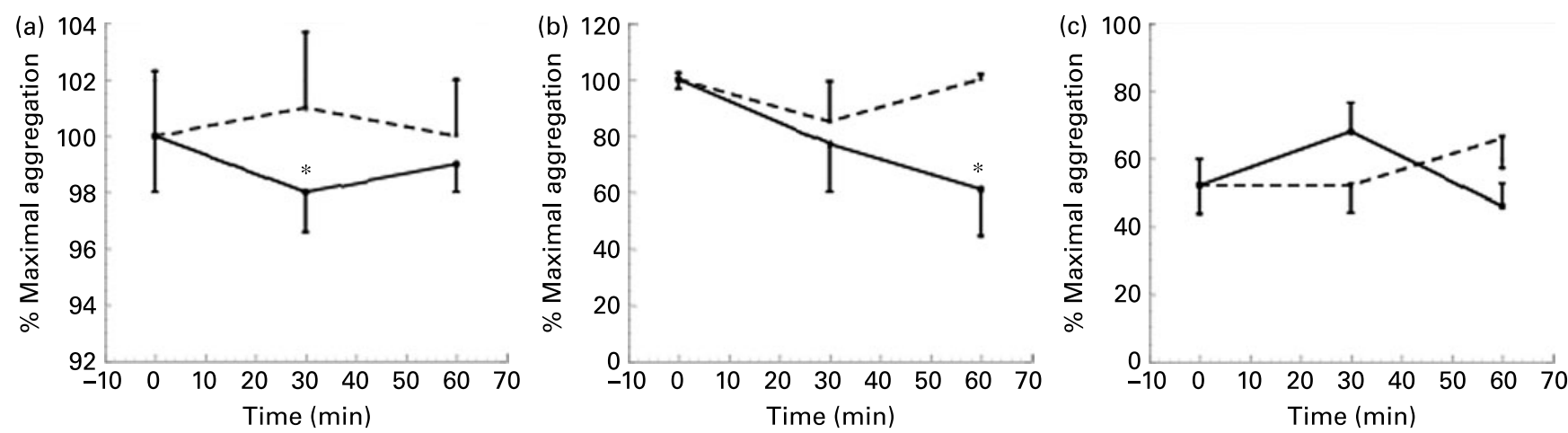

Fig. 1. Maximal platelet aggregation (\%) at baseline, 30 and 60 min after coffee (- - ) and caffeine (- - ) consumption ( $n$ 10). The aggregation was induced by collagen $(3 \mu \mathrm{g} / \mathrm{ml})(\mathrm{a})$; arachidonic acid $(0.5 \mu \mathrm{M})(\mathrm{b})$; ADP $(2 \mu \mathrm{M})(\mathrm{c})$. Values are means with their standard errors depicted by vertical bars. Mean values were significantly different from those of time 0 (repeated-measures ANOVA followed by Tukey's test): ${ }^{*} P<0.05$. 


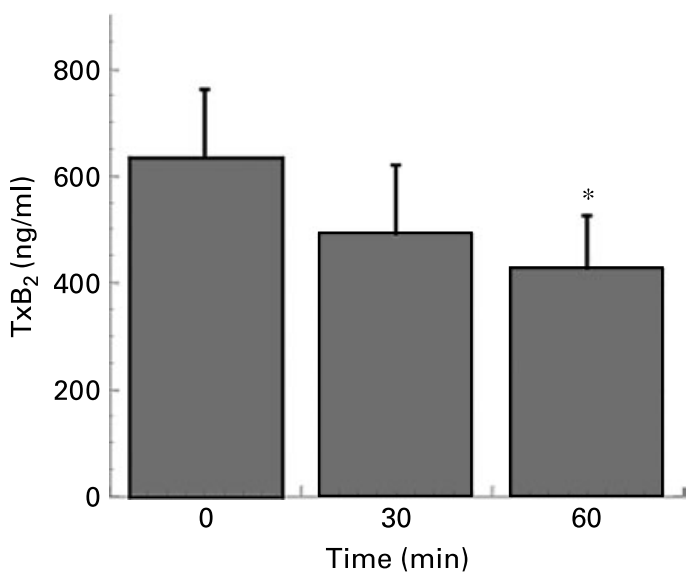

Fig. 2. Thromboxane $B_{2}$ (TxB2) production in platelets separated at time 0 30 and $60 \mathrm{~min}$ after coffee consumption $(n 6)$. Platelets were activated using collagen $(3 \mu \mathrm{g} / \mathrm{ml})$. Values are means with their standard errors depicted by vertical bars. Mean values were significantly different from those of time 0 (repeated-measures ANOVA followed by Tukey's test): * $P<0.05$.

caffeine intake did not affect platelet aggregation induced by any of the agonists (Fig. 1). Coffee and caffeine intake induced a similar increase in plasma caffeine concentrations, which reached the same peak concentration $60 \mathrm{~min}$ after both supplementations (Fig. 3). Even if the kinetic of absorption was different, we can exclude some effect of caffeine on platelet aggregation. In fact, $60 \mathrm{~min}$ after caffeine intake (when plasma caffeine concentration was equal to the concentration reached after coffee drinking), no effect of caffeine on platelet aggregation was observed. Similar results were obtained by Rein et al. ${ }^{(21)}$, who did not find any effect on ADP-induced platelet aggregation after acute intake of caffeine $(17 \mathrm{mg})$. On the contrary, Varani et al. ${ }^{(22)}$ observed that chronic caffeine intake could affect ADP-induced platelet aggregation, but only when the intake lasted longer than 1

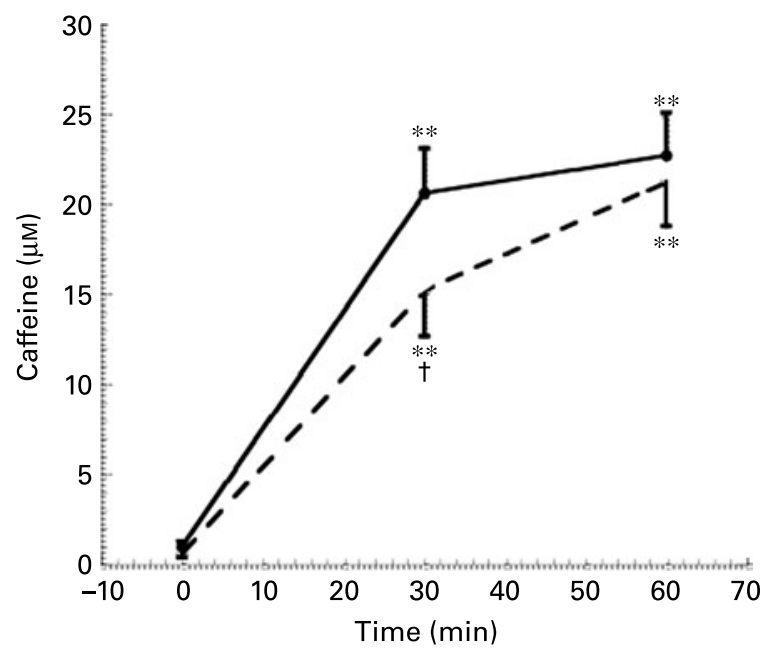

Fig. 3. Caffeine concentration at baseline, 30 and 60 min after coffee (- - -) and caffeine (- - ) consumption ( $n$ 10). Values are means with their standard errors depicted by vertical bars. Mean values were significantly different from those of time 0 (repeated-measures ANOVA followed by Tukey's test) ${ }^{\star \star} P<0.01$. Mean values were significantly different from those of coffee (repeated-measures ANOVA followed by Tukey's test): $\uparrow P<0.05$. week and was higher than $400 \mathrm{mg} / \mathrm{d}$. According to the present results, Varani et al. ${ }^{(22)}$ did not observe any effect of caffeine on platelet aggregation after acute intake.

The capacity of coffee to inhibit platelet aggregation has been already demonstrated, but only in an animal model. Bydlowski et al. ${ }^{(19)}$ demonstrated that an intravenous administration of coffee extracts inhibited ex vivo arachidonic acid and ADP-induced platelet aggregation in rabbits. In man, Polagruto et al. ${ }^{(20)}$ did not find significant modification of platelet function 2 and $6 \mathrm{~h}$ after coffee drinking. However, their results are scarcely comparable with the present data, as platelet function was estimated using a completely different methodology (the measure of the adrenalin/collagen or ADP/ collagen induced clotting time) and time-points.

Apart from coffee, several papers report an effect of specific food items on platelet aggregation in vivo in man, both in acute and chronic studies. An antiplatelet effect has been demonstrated for fruit juice ${ }^{(20)}$, red wine ${ }^{(18)}$, onion ${ }^{(27)}$, tea ${ }^{(17,28)}$ and tomato ${ }^{(29)}$ (for a review, see Nardini et al. ${ }^{(30)}$ )' These findings support the role of the diet (as a whole and/ or its single components) in the modulation of the platelet network and confirm the important role of diet in the prevention of CVD.

Looking for the molecular mechanism through which coffee can affect platelet aggregation, we measured the capacity of coffee drinking to affect collagen-induced platelet TxA2 formation. The present results demonstrated that coffee inhibited both collagen and arachidonic acid-induced platelet aggregation, but it had no effect on ADP-induced platelet aggregation. Differently from ADP, the platelet activation pathways induced by arachidonic acid and collagen are both mediated by cyclo-oxygenase, through the formation of TxA2, which further stimulates aggregation. As shown in Fig. 2, platelets collected $60 \mathrm{~min}$ after coffee drinking and activated with collagen released significantly less TxB2 than those collected before drinking. The present result is in agreement with literature data reporting that coffee inhibits in vitro $\mathrm{TxB} 2$ generation in rabbit platelets ${ }^{(19)}$. Thus, coffee affects the signal transduction pathway, which leads to aggregation through the inhibition of one of the enzyme activities that lies upstream of the formation of TxB2 in the signalling cascade.

It is well known that phenolic compounds can inhibit in vitro and ex vivo platelet aggregation ${ }^{(11,23)}$. Their anti-aggregating

Table 1. Concentration of total phenolic acids ( $\mathrm{ng} / \mathrm{mg}$ protein) in platelets before and after coffee drinking ( $n$ 10)

(Mean values with their standard errors)

\begin{tabular}{|c|c|c|c|c|c|c|c|c|}
\hline \multirow{2}{*}{$\begin{array}{l}\text { Time } \\
\text { (min) }\end{array}$} & \multicolumn{2}{|c|}{$\begin{array}{c}\text { Caffeic acid } \\
\text { (ng/mg } \\
\text { protein) }\end{array}$} & \multicolumn{2}{|c|}{$\begin{array}{c}\text { p-Coumaric } \\
\text { acid } \\
\text { (ng/mg } \\
\text { protein) }\end{array}$} & \multicolumn{2}{|c|}{$\begin{array}{c}\text { Ferulic acid } \\
\text { (ng/mg } \\
\text { protein) }\end{array}$} & \multicolumn{2}{|c|}{$\begin{array}{l}\text { Isoferulic } \\
\text { acid } \\
\text { (ng/mg } \\
\text { protein) }\end{array}$} \\
\hline & Mean & SEM & Mean & SEM & Mean & SEM & Mean & SEM \\
\hline 0 & 0.3 & 0.1 & $1 \cdot 1$ & 0.4 & 1.0 & 0.4 & 0.2 & 0.1 \\
\hline 30 & $1 \cdot 7^{*}$ & 0.4 & $1 \cdot 8^{*}$ & 0.5 & $1 \cdot 9^{\star *}$ & 0.4 & $0.7^{\star *}$ & 0.1 \\
\hline 60 & $2 \cdot 4^{\star \star}$ & 0.6 & 1.4 & 0.5 & $1 \cdot 7^{\star *}$ & 0.3 & 0.9 & 0.4 \\
\hline
\end{tabular}

Mean values were significantly different from those of time 0 (repeated-measures ANOVA followed by Tukey's test): ${ }^{\star} P \leq 0.05,{ }^{\star \star} P \leq 0.01$. 
(a)

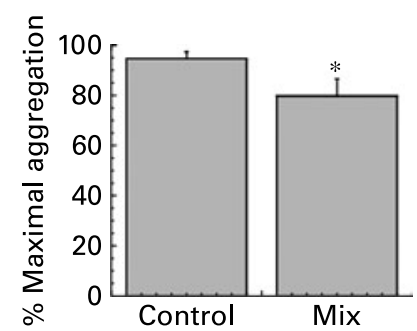

(b)

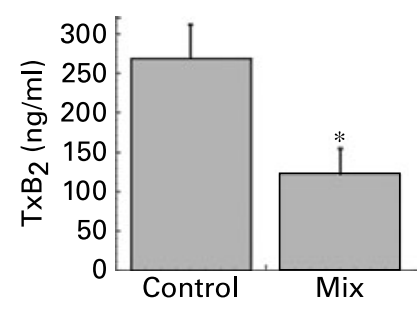

Fig. 4. Maximal platelet aggregation (\%) (a) and thromboxane $B_{2}$ (TxB2) release (b) $(n 5)$. Platelet-rich plasma was pre-incubated for $30 \mathrm{~min}$ at $37^{\circ} \mathrm{C}$ alone (control) or with a mix of caffeic acid $(2.4 \mathrm{ng} / \mathrm{mg}$ protein), ferulic acid (1.9 ng/mg protein), $p$-coumaric acid $(1.8 \mathrm{ng} / \mathrm{mg}$ protein) and isoferulic acid $(0.9 \mathrm{ng} / \mathrm{mg}$ protein). The aggregation was induced by collagen $(3 \mu \mathrm{g} / \mathrm{ml})$. Values are means with their standard errors depicted by vertical bars. Mean values were significantly different from those of the control (repeatedmeasures ANOVA followed by Tukey's test): ${ }^{\star} P<0.05$.

activity has been attributed to several mechanisms, among them the capacity to inhibit TxA2 generation ${ }^{(31,32)}$. Coffee contains several phenolic compounds, which are absorbed and rapidly metabolized in $\operatorname{man}^{(6,33)}$. In a previous study we demonstrated that coffee drinking induces a significant increase in plasma caffeic acid, which reaches micromolar concentrations $1 \mathrm{~h}$ after coffee intake ${ }^{(6)}$.

The incorporation of polyphenols into circulating cells after the intake of a polyphenol-rich food has not been demonstrated yet. In the present study, we demonstrate for the first time that metabolites of phenolic acids are incorporated in human platelets after a single oral dose of coffee.

It is important to underline that the evaluation of the actual bioavailability of polyphenols and their subsequent interaction with cells and tissues is a prerequisite for the real understanding of their physiological effect. In fact, many of the effects claimed for these compounds are exerted inside the cells ${ }^{(34,35)}$, but, unfortunately, no direct evidence exists about the 'physiological' presence of these compounds in cells in in vivo studies. Information on polyphenol tissue distribution is still very scarce, and available data concern only animal models. Animal studies, mostly using radiolabelled compounds, have shown that phenolic compounds are able to penetrate tissues, particularly those in which they are metabolized (intestine and liver ${ }^{(36-38)}$; for a review, see Manach et al. $\left.{ }^{(39)}\right)$. In tissues phenolic compounds occur prevalently in conjugated forms, indicating that the ingested phenolics are extensively and rapidly metabolized ${ }^{(40,41)}$. To our knowledge, only three studies report data on the occurrence of polyphenols in human cells in vivo ${ }^{(42-44)}$, and, among these, only one study evaluates their presence in human blood cells. In the present study, apigenin metabolites were found in human erythrocytes, but no increase in their cellular concentration was observed after apigenin-rich parsley consumption $^{(44)}$.

With the exception of isoferulic acid, all the phenolic acids measured in platelets after coffee drinking were present in coffee brew, even if in bound forms as esters of quinic acid (data not shown). In coffee, the most abundant of these esters is chlorogenic acid, whose phenolic moiety is represented by caffeic acid ${ }^{(5)}$. Isoferulic acid is a metabolite of caffeic acid and is not present, as such, in coffee.
Its increase after coffee drinking indicates that caffeic acid is extensively metabolized, but we cannot speculate if its metabolism takes place before or after the incorporation into platelets. All the phenolic acids measured into platelets were present in conjugated forms, indicating a wide and rapid metabolic process. Yet, preliminary evidence obtained with an enzymatic hydrolytic procedure seems to indicate that most of the phenolic acids are present in platelets as glucuronates and sulphates (data not shown).

It must be evidenced that phenolic acid concentration inside platelets is sufficiently high to explain coffee anti-aggregative effects. The sum of platelet phenolic acid concentration, in fact, reaches about $6 \mathrm{ng} / \mathrm{mg}$ protein at 30 and $60 \mathrm{~min}$. A raw calculation (based on a mean platelet volume and protein content) lets us estimate that caffeic acid alone can reach an intracellular concentration of about $2 \mu \mathrm{M}$. To test if phenolic acids, at the concentration observed in platelets after coffee drinking, were able to affect platelet aggregation, we ran in vitro experiments, using a mix of the different phenolic acids at the concentrations measured in vivo. As shown in Fig. 4, the mix is capable of significantly inhibiting collagen-induced platelet aggregation and collagen-induced TxB2 formation. It is well known that phenolic acids are efficient antioxidants ${ }^{(45)}$ and caffeic acid is a good inhibitor of lipoxygenase $^{(46)}$, cyclo-oxygenase ${ }^{(47)}$ and kinases ${ }^{(48)}$. All these activities could be critical for the anti-aggregative capacity of phenolic acids.

We are aware that phenolic acids incorporated into platelets are not in their free form, but in conjugated forms, likely glucuronates and sulphates. Since at the moment the appropriate standard compounds are not commercially available, we cannot determinate if these forms are more or less active than their respective free forms. Scarce information is available concerning the potential activity of the metabolites of polyphenols. Conjugated forms of quercetin, one of the most abundant flavonoids in the human diet, retain antioxidant activity, although to a lesser extent in respect to quercetin ${ }^{(49)}$. The antioxidant activity of ferulic acid glucuronide is stronger than that exhibited by ferulic acid ${ }^{(50)}$. However, some polyphenol metabolites (quercetin tetrasulphate and genistein sulphates) have been reported to have lower antiplatelet activities than their parent molecules ${ }^{(32,51)}$. The possibility exists that the free forms penetrate into the cells, where a subsequent conjugation reaction takes place. This assumption is plausible since studies have shown the presence of UDP-glucuronosyltransferase ${ }^{(52)}$ and phenolsulphotransferase ${ }^{(53)}$ in platelets and an in vitro experiment demonstrates that metabolites of radiolabelled-hydroxytyrosol are rapidly formed after the incubation of hydroxytyrosol in whole human blood ${ }^{(54)}$.

Data presented here indicate that drinking $200 \mathrm{ml}$ coffee (one cup) inhibits platelet aggregation in man. We also demonstrated that coffee phenolic acids penetrate into platelets, and that they are present in platelets at concentrations that are able to inhibit platelet aggregation in vitro. Clearly, we cannot exclude that other non-phenolic coffee compounds, different from caffeine, could contribute to the antiplatelet effect of coffee observed ex vivo.

For a long time the relationship between coffee and cardiovascular risk has been controversial. However, recent epidemiological studies strongly suggest the existence of a J-shaped relationship linking coffee consumption and CVD 
risk $^{(1-3)}$. It is reasonable to hypothesize that such $\mathrm{J}$-shaped correlation is the direct result of the combined positive and negative action of different molecules present in coffee. As it has been demonstrated that ex vivo platelet aggregation is related to CVD mortality ${ }^{(10)}$, the anti-aggregative action of coffee phenolic acids could represent the bright side of coffee.

\section{Acknowledgements}

The study was supported by grants from the Institute for Scientific Information on Coffee (ISIC) in La Tour-de-Peilz (Switzerland) and the Physiological Effects of Coffee Committee (PEC), in La Tour-de-Peilz (Switzerland). There is not any actual or potential conflicts of interest capable of influencing judgement on the part of any author. We thank all the volunteers for their participation. Daniela Salzano and Monica Brancorsini are thanked for their nursing assistance. Kariklia Pascucci is acknowledged for her kind support in the daily laboratory work. We would like also to thank Sigma-Tau (Pomezia, Italy) for donating caffeine capsules.

\section{References}

1. Kleemola P, Jousilahti P, Pietinen P, Vartiainen E \& Tuomilehto J (2000) Coffee consumption and the risk of coronary heart disease and death. Arch Intern Med 160, 3393-3400.

2. Panagiotakos DB, Pitsavos C, Chrysohoou C, Kokkinos P, Toutouzas P \& Stefanadis C (2003) The J-shaped effect of coffee consumption on the risk of developing acute coronary syndromes: the CARDIO2000 case-control study. J Nutr 133, $3228-3232$.

3. Andersen LF, Jacobs DR Jr, Carlsen MH \& Blomhoff R (2006) Consumption of coffee is associated with reduced risk of death attributed to inflammatory and cardiovascular diseases in the Iowa Women's Health Study. Am J Clin Nutr 83, 1039-1046.

4. Natella F, Nardini M, Giannetti I, Dattilo C \& Scaccini C (2002) Coffee drinking influences plasma antioxidant capacity in humans. J Agric Food Chem 50, 6211-6216.

5. Clifford MN (1985) Chlorogenic acids. In Coffee, pp. 153-202 [RJ Clarke and R Macrae, editors]. London: Elsevier Applied Science.

6. Nardini M, Cirillo E, Natella F \& Scaccini C (2002) Absorption of phenolic acids in humans after coffee consumption. J Agric Food Chem 50, 5735-5741.

7. Hertog MG, Kromhout D, Aravanis C, Blackburn H, Buzina R, Fidanza F, Giampaoli S, Jansen A, Menotti A, Nedeljkovic S, et al. (1995) Flavonoid intake and long-term risk of coronary heart disease and cancer in the seven countries study. Arch Intern Med 155, 381-386.

8. Arts IC, Hollman PC, Feskens EJ, Bueno de Mesquita HB \& Kromhout D (2001) Catechin intake might explain the inverse relation between tea consumption and ischemic heart disease: the Zutphen Elderly Study. Am J Clin Nutr 74, 227-232.

9. Fuster V, Badimon L, Badimon JJ \& Chesebro JH (1992) The pathogenesis of coronary artery disease and the acute coronary syndromes (1). $N$ Engl J Med 326, 242-250.

10. Thaulow E, Erikssen J, Sandvik L, Stormorken H \& Cohn PF (1991) Blood platelet count and function are related to total and cardiovascular death in apparently healthy men. Circulation 84, 613-617.

11. Freedman JE, Parker C III, Perlman JA, Frei B, Ivanov V, Deak LR, Iafrati MD \& Folts JD (2001) Select flavonoids and whole juice from purple grapes inhibit platelet function and enhance nitric oxide release. Circulation 103, 2792-2798.

12. Olas B, Wachowicz B, Saluk-Juszczak J \& Zielinski T (2002) Effect of resveratrol, a natural polyphenolic compound, on platelet activation induced by endotoxin or thrombin. Thromb Res 107, 141-145.

13. Demrow HS, Slane PR \& Folts JD (1995) Administration of wine and grape juice inhibits in vivo platelet activity and thrombosis in stenosed canine coronary arteries. Circulation 91, $1182-1188$.

14. Luceri C, Giannini L, Lodovici M, Antonucci E, Abbate R, Masini E \& Dolara P (2007) p-Coumaric acid, a common dietary phenol, inhibits platelet activity in vitro and in vivo. Br J Nutr 97, 458-463.

15. Pignatelli P, Pulcinelli FM, Celestini A, Lenti L, Ghiselli A, Gazzaniga PP \& Violi F (2000) The flavonoids quercetin and catechin synergistically inhibit platelet function by antagonizing the intracellular production of hydrogen peroxide. Am J Clin Nutr 72, 1150-1155.

16. Lill G, Voit S, Schror K \& Weber AA (2003) Complex effects of different green tea catechins on human platelets. FEBS Lett 546, 265-270.

17. Hodgson JM, Puddey IB, Burke V, Beilin LJ, Mori TA \& Chan SY (2002) Acute effects of ingestion of black tea on postprandial platelet aggregation in human subjects. Br J Nutr 87, 141-145.

18. Pignatelli P, Lenti L, Pulcinelli FM, Catasca R, Saccani G, Germano G, Marcoccia A, Silvestri MA, Ghiselli A \& Violi F (2002) Red and white wine differently affect collagen-induced platelet aggregation. Pathophysiol Haemost Thromb 32, 356-358.

19. Bydlowski SP, Yunker RL, Rymaszewski Z \& Subbiah MT (1987) Coffee extracts inhibit platelet aggregation in vivo and in vitro. Int J Vitam Nutr Res 57, 217-223.

20. Polagruto JA, Schramm DD, Wang-Polagruto JF, Lee L \& Keen CL (2003) Effects of flavonoid-rich beverages on prostacyclin synthesis in humans and human aortic endothelial cells: association with ex vivo platelet function. J Med Food 6, 301-308.

21. Rein D, Paglieroni TG, Wun T, Pearson DA, Schmitz HH, Gosselin R \& Keen CL (2000) Cocoa inhibits platelet activation and function. Am J Clin Nutr 72, 30-35.

22. Varani K, Portaluppi F, Gessi S, Merighi S, Ongini E, Belardinelli L \& Borea PA (2000) Dose and time effects of caffeine intake on human platelet adenosine $\mathrm{A}(2 \mathrm{~A})$ receptors: functional and biochemical aspects. Circulation 102, 285-289.

23. Violi F, Pignatelli P \& Pulcinelli FM (2002) Synergism among flavonoids in inhibiting platelet aggregation and $\mathrm{H}_{2} \mathrm{O}_{2}$ production. Circulation 105, e53.

24. Blanchard J, Mohammadi JD \& Conrad KA (1980) Improved liquid-chromatographic determination of caffeine in plasma. Clin Chem 26, 1351-1354.

25. Nardini M, Natella F, Scaccini C \& Ghiselli A (2006) Phenolic acids from beer are absorbed and extensively metabolized in humans. J Nutr Biochem 17, 14-22.

26. Lowry OH, Rosebrough NJ, Farr AL \& Randall RJ (1951) Protein measurement with the Folin phenol reagent. $J$ Biol Chem 193, 265-275.

27. Hubbard GP, Wolffram S, de Vos R, Bovy A, Gibbins JM \& Lovegrove JA (2006) Ingestion of onion soup high in quercetin inhibits platelet aggregation and essential components of the collagen-stimulated platelet activation pathway in man: a pilot study. Br J Nutr 96, 482-488.

28. Steptoe A, Gibson EL, Vuononvirta R, Hamer M, Wardle J, Rycroft JA, Martin JF \& Erusalimsky JD (2007) The effects of chronic tea intake on platelet activation and inflammation: a double-blind placebo controlled trial. Atherosclerosis 193, $277-282$ 
29. O'Kennedy N, Crosbie L, Whelan S, Luther V, Horgan G, Broom JI, Webb DJ \& Duttaroy AK (2006) Effects of tomato extract on platelet function: a double-blinded crossover study in healthy humans. Am J Clin Nutr 84, 561-569.

30. Nardini M, Natella F \& Scaccini C (2007) Role of dietary polyphenols in platelet aggregation. A review of the supplementation studies. Platelets 18, 224-243.

31. Tzeng SH, Ko WC, Ko FN \& Teng CM (1991) Inhibition of platelet aggregation by some flavonoids. Thromb Res 64, 91-100.

32. Guglielmone HA, Agnese AM, Nunez Montoya SC \& Cabrera JL (2005) Inhibitory effects of sulphated flavonoids isolated from Flaveria bidentis on platelet aggregation. Thromb Res 115, 495-502.

33. Olthof MR, Hollman PC \& Katan MB (2001) Chlorogenic acid and caffeic acid are absorbed in humans. $J$ Nutr 131, 66-71.

34. Oak MH, El Bedoui J, Anglard P \& Schini-Kerth VB (2004) Red wine polyphenolic compounds strongly inhibit pro-matrix metalloproteinase- 2 expression and its activation in response to thrombin via direct inhibition of membrane type 1-matrix metalloproteinase in vascular smooth muscle cells. Circulation 110, $1861-1867$.

35. Dasgupta B \& Milbrandt J (2007) Resveratrol stimulates AMP kinase activity in neurons. Proc Natl Acad Sci U S A 104, $7217-7222$.

36. Suganuma $\mathrm{M}$, Okabe $\mathrm{S}$, Oniyama $\mathrm{M}$, Tada $\mathrm{Y}$, Ito $\mathrm{H} \&$ Fujiki $\mathrm{H}$ (1998) Wide distribution of $\left[{ }^{3} \mathrm{H}\right](-)$-epigallocatechin gallate, a cancer preventive tea polyphenol, in mouse tissue. Carcinogenesis 19, 1771-1776.

37. Tsuda T, Horio F \& Osawa T (1999) Absorption and metabolism of cyanidin 3-O-beta-D-glucoside in rats. FEBS Lett 449, 179-182.

38. de Boer VC, Dihal AA, van der Woude H, Arts IC, Wolffram S, Alink GM, Rietjens IM, Keijer J \& Hollman PC (2005) Tissue distribution of quercetin in rats and pigs. J Nutr 135, $1718-1725$.

39. Manach C, Scalbert A, Morand C, Remesy C \& Jimenez L (2004) Polyphenols: food sources and bioavailability. Am J Clin Nutr 79, 727-747.

40. Abd El Mohsen MM, Kuhnle G, Rechner AR, Schroeter H, Rose S, Jenner P \& Rice-Evans CA (2002) Uptake and metabolism of epicatechin and its access to the brain after oral ingestion. Free Radic Biol Med 33, 1693-1702.

41. Graf BA, Mullen W, Caldwell ST, Hartley RC, Duthie GG, Lean ME, Crozier A \& Edwards CA (2005) Disposition and metabolism of $\left[2{ }^{14} \mathrm{C}\right]$ quercetin- 4 -glucoside in rats. Drug Metab Dispos 33, 1036-1043.

42. Hong SJ, Kim SI, Kwon SM, Lee JR \& Chung BC (2002) Comparative study of concentration of isoflavones and lignans in plasma and prostatic tissues of normal control and benign prostatic hyperplasia. Yonsei Med J 43, 236-241.

43. Maubach J, Bracke ME, Heyerick A, Depypere HT, Serreyn RF, Mareel MM \& De Keukeleire D (2003) Quantitation of soyderived phytoestrogens in human breast tissue and biological fluids by high-performance liquid chromatography. J Chromatogr B Analyt Technol Biomed Life Sci 784, 137-144.

44. Meyer H, Bolarinwa A, Wolfram G \& Linseisen J (2006) Bioavailability of apigenin from apiin-rich parsley in humans. Ann Nutr Metab 50, 167-172.

45. Nardini M, D'Aquino M, Tomassi G, Gentili V, Di Felice M \& Scaccini C (1995) Inhibition of human low-density lipoprotein oxidation by caffeic acid and other hydroxycinnamic acid derivatives. Free Radic Biol Med 19, 541-552.

46. de la Puerta R, Ruiz Gutierrez V \& Hoult JR (1999) Inhibition of leukocyte 5-lipoxygenase by phenolics from virgin olive oil. Biochem Pharmacol 57, 445-449.

47. Huang MT, Lysz T, Ferraro T, Abidi TF, Laskin JD \& Conney AH (1991) Inhibitory effects of curcumin on in vitro lipoxygenase and cyclooxygenase activities in mouse epidermis. Cancer Res 51, 813-819.

48. Nardini M, Scaccini C, Packer L \& Virgili F (2000) In vitro inhibition of the activity of phosphorylase kinase, protein kinase $\mathrm{C}$ and protein kinase A by caffeic acid and a procyanidin-rich pine bark (Pinus marittima) extract. Biochim Biophys Acta 1474, 219-225.

49. Manach C, Morand C, Crespy V, Demigne C, Texier O, Regerat F \& Remesy C (1998) Quercetin is recovered in human plasma as conjugated derivatives which retain antioxidant properties. FEBS Lett 426, 331-336.

50. Ohta T, Nakano T, Egashira Y \& Sanada H (1997) Antioxidant activity of ferulic acid beta-glucuronide in the LDL oxidation system. Biosci Biotechnol Biochem 61, 1942-1943.

51. Rimbach G, Weinberg PD, de Pascual-Teresa S, et al. (2004) Sulfation of genistein alters its antioxidant properties and its effect on platelet aggregation and monocyte and endothelial function. Biochim Biophys Acta 1670, 229-237.

52. Nowell SA, Leakey JE, Warren JF, Lang NP \& Frame LT (1998) Identification of enzymes responsible for the metabolism of heme in human platelets. $J$ Biol Chem 273, $33342-33346$.

53. Littlewood J, Glover V, Sandler M, Petty R, Peatfield R \& Rose FC (1982) Platelet phenolsulphotransferase deficiency in dietary migraine. Lancet 1, 983-986.

54. D'Angelo S, Manna C, Migliardi V, Mazzoni O, Morrica P, Capasso G, Pontoni G, Galletti P \& Zappia V (2001) Pharmacokinetics and metabolism of hydroxytyrosol, a natural antioxidant from olive oil. Drug Metab Dispos 29, 1492-1498. 